Article

\title{
Impacts of Erosion on the Sustainability of Organic Olive Groves: A Case Study (Estepa Region, Southwestern Spain)
}

\author{
Antonio Alberto Rodríguez Sousa ${ }^{1,2, *(\mathbb{D})}$, Carlos Parra-López ${ }^{3} \mathbb{D}$, Samir Sayadi-Gmada ${ }^{3} \mathbb{D}$, Jesús M. Barandica ${ }^{2} \mathbb{D}$ \\ and Alejandro J. Rescia ${ }^{2, *(D)}$
}

1 Biodiversity and Conservation Area, Department of Biology and Geology, Physics and Inorganic Chemistry, School of Experimental Sciences and Technology (ESCET), University Rey Juan Carlos (URJC), 28933 Madrid, Spain

2 Department of Biodiversity, Ecology and Evolution (BEE), Faculty of Biological Sciences, University Complutense of Madrid (UCM), 28040 Madrid, Spain; jmbarand@ucm.es

3 Department of Agrifood System Economics, Institute of Agricultural and Fisheries Research and Training (IFAPA), Ministry of Agriculture, Livestock, Fisheries and Sustainable Development-Government of Andalusia, P.O. Box 2027, 18080 Granada, Spain; carlos.parra@juntadeandalucia.es (C.P.-L.); samir.sayadi@juntadeandalucia.es (S.S.-G.)

* Correspondence: antonioalberto.sousa@urjc.es or antonr05@ucm.es (A.A.R.S.); alejo296@bio.ucm.es (A.J.R.); Tel.: +34-91-394-50-85 (A.A.R.S.); +34-91-394-47-39 (A.J.R.)

check for updates

Citation: Rodríguez Sousa, A.A.; Parra-López, C.; Sayadi-Gmada, S.; Barandica, J.M.; Rescia, A.J. Impacts of Erosion on the Sustainability of Organic Olive Groves: A Case Study (Estepa Region, Southwestern Spain). Sustainability 2021, 13, 7983. https:// doi.org/10.3390/su13147983

Academic Editor: Anastasios Michailidis

Received: 5 June 2021

Accepted: 15 July 2021

Published: 16 July 2021

Publisher's Note: MDPI stays neutral with regard to jurisdictional claims in published maps and institutional affiliations.

Copyright: (C) 2021 by the authors Licensee MDPI, Basel, Switzerland. This article is an open access article distributed under the terms and conditions of the Creative Commons Attribution (CC BY) license (https:/ / creativecommons.org/licenses/by/ $4.0 /)$.

\begin{abstract}
Spain has more than 2.5 M ha of olive groves, with $60 \%$ of this area (i.e., $1.5 \mathrm{M}$ ha) concentrated in the region of Andalusia (Southern Spain). Assuming the socio-ecological characteristics of these crops, of which their contribution to ecosystemic services (ES) is fundamental for society, it is highly relevant to direct their management towards practices that guarantee their durability. Organic management of olive groves constitutes a multifunctional model that contributes to ensuring its sustainability and represents $2.4-3.5 \%$ of the olive grove area in Spain. Taking the Protected Designation of Origin (PDO) Estepa (Southwestern Spain) as a study model, where organic olive groves are novel, a study of the impacts of erosion on the economic, social, and environmental factors associated with this management was carried out in addition to estimating its impacts. The results showed how organic management promotes edaphic fertility, keeping the levels of diffuse pollution under the legislative limits. Although the increase in erosion has negative effects on the sustainability/durability of agricultural holdings, organic management consolidates a sustainable model that satisfies farmers' demands. Therefore, organic farming is a model that focuses on the correct use of natural resources associated with the geographical region of study, and contributes to increasing the sustainability of olive groves.
\end{abstract}

Keywords: biological diversity; common agricultural policy; ecosystem services; diffuse pollution; multifunctional agriculture; socio-ecosystems; soil fertility; soil loss

\section{Introduction}

Olive farming systems are traditional landscapes linked to Mediterranean climates that have a deep-rooted socio-cultural tradition [1,2]. Although olive groves are represented throughout the world, Europe, with 175 million hectares ( $\mathrm{M} \mathrm{ha}$ ) of useful agricultural surface (UAS), is the continent with the largest area devoted to this crop, with 5 million hectares ( $\mathrm{M} \mathrm{ha}$ ), representing $2.86 \%$ of the European agricultural area, according to EUROSTAT and CORINE Land Cover data [3,4]. Specifically, the socio-economic relevance of these crops is maximised in Southern Europe, with countries, such as Greece, with more than $1 \mathrm{M}$ ha of olive groves, Italy, with an area greater than $1.20 \mathrm{M}$ ha, and Spain, where the area with olive groves exceeds $2.5 \mathrm{M}$ ha [5-7]. It is worth highlighting the relevance of olive growing systems in Spain, where the surface area is concentrated in Andalusia (i.e., Southern Spain), with more than 1.50 M ha [5-8]. In Andalusia, olive cultivation represents $26 \%$ of agricultural production and $31 \%$ of plant production, forming broad 
monocultures that shape the Andalusian landscape, generating 32\% of regional agricultural employment and a contribution to agricultural income of $20 \%$ [9]. In this sense, following data from the International Olive Council from 2015 [6], it is worth highlighting that Spain is the leading olive oil producing country, with an annual average production level greater than 1.20 tonnes $(t)$ in the 2009-2015 campaigns. Specifically, Andalusia has an average production of $1.11 \mathrm{t}$ of oil per year, producing $86.38 \%$ of the national olive oil in Spain [6-10]. In addition to their productive dimension (i.e., supply ES), the multifunctional character of these agricultural systems and their fundamental role in the provision of ecosystem services to society (ES) must be highlighted [1,8]. Thus, olive groves, from a landscape perspective, contribute by generating several services to society, like regulatory/regulating ES (i.e., control of erosion, sequestration of atmospheric $\mathrm{CO}_{2}$ as a measure to mitigate global warming and reduce terrestrial and atmospheric pollution) and cultural ES, where olive oil tourism is a rural development measure increasingly demanded by society at national and international levels [11-13]. Finally, olive groves also provide transversal ES (i.e., services encompassing the ecological processes necessary for the production of other ES), where, despite the monoculture nature of the olive grove, the boundaries between plots and plant covers used in some crops as erosion mitigation measures act as reservoirs for agrobiodiversity, hosting 17\% of Andalusian vascular flora and a wealth of arthropods and wintering and nesting birds [9,13-15].

Traditionally, olive groves have been extensively managed through the use of machinery being conditioned by the slope of the land (i.e., up to $20 \%$ ) $[16,17]$; however, the vulnerability and productive-economic instability of these systems, where meteorological factors condition olive yields, together with the increase in demand for food products related to the olive grove, have led to a change in agricultural management models over the last few decades $[18,19]$. While there has been an agricultural abandonment of olive groves by farmers with marginal and unprofitable farms, and an agricultural intensification through the indiscriminate addition of chemical fertilisers and irrigation to farms to increase production $[2,20,21]$, in recent years, many olive-growing regions have tended towards the adoption of management models based on multifunctional agricultural models (i.e., MFA approach), with the aim of promoting product quality, generating a revaluation of olive oil at source [22-24].

Within the MFA approach, integrated and organic management of olive groves stand out, promoting the stabilisation of its productive yield together with minimum environmental impacts, with laminar soil erosion being the main threat to agricultural sustainability [24-27]. Although both approaches promote the multifunctionality of the olive grove, they have different management practices. Both agricultural models allow the incorporation of deficit irrigation, a practice that optimises water efficiency by adding water volumes of up to $1500 \mathrm{~m}^{3} \mathrm{ha}^{-1}$ to the crop only in times of water stress $[16,28]$. However, in integrated farming, the addition of chemical fertilisers is allowed to a limited extent, whereas organic farming only allows the use of organic fertilisers; thus, promoting proper soil maintenance and fertilisation [16,24]. Although integrated olive management has been a widely adopted model at the European level, it is worth noting specifically how, in recent years, there has been an increased demand for organic olive groves [29]. At the European level, while in the early 1990s there were barely 20,000 organically managed farms, there are now more than 350,000 farms using this management [30]. In Spain, organic olive groves are still incipient, representing between 63,600-92,750 ha according to different bibliographical sources (i.e., $2.40-3.50 \%$ of the national olive grove), of which approximately 55,000-80,000 ha are located in Andalusia [4,9,17,29,30]. The observed expansion of organic olive groves is mainly due to changes in the common agricultural policy (CAP), together with farmers' and society's demands [31,32]. On the one hand, the current CAP (i.e., 2014-2020) and its future prospects (i.e., CAP post-2020) no longer shape a policy based on subsidies directly proportional to production, instead encouraging the adoption of agricultural practices aimed at maximising crop sustainability and rural development on a regional scale, placing value on the contribution of non-productive ES of the olive 
grove, with the organic model being an environmentally friendly management aimed at promoting the sustainability of these systems $[8,33,34]$. On the other hand, this agricultural model can respond to farmers' demands, based on obtaining economic stability, and to the existing social demands towards agriculture, where the main focus is on obtaining quality products based on food security [32,35].

In organic olive groves, agro-environmental measures such as the implementation of living plant covers to minimise the impact of erosion processes are promoted [8,29]. This farm practices, together with the current regulatory and legislative framework (i.e., CAP) that regulates olive groves, make it necessary to carry out research that analyses the sustainability of this agricultural model in a multidimensional way. In this way, it is possible to highlight its advantages and vulnerabilities to farmers and decision-makers, with the aim of being able to optimally manage any olive-growing territory $[17,24]$. Thus, in this research, a detailed analysis of the organic olive grove of the Protected Designation of Origin (PDO) Estepa, in Seville (Andalusia, Spain) was carried out. This region has 39,463 ha of olive groves that extend as a monoculture over almost $70 \%$ of its agricultural area, and has an annual production yield of approximately $30 \mathrm{M} \mathrm{kg}$ of oil, representing almost $50 \%$ of olive production in Seville $[9,36]$. From a socio-economic point of view, olive growing in the Estepa region generates the labour of 5500 farmers, and an annual income of $224 \mathrm{M} €$ (i.e., $10 \%$ of the daily wages of the province) [37]. Although integrated olive groves predominate, the PDO Estepa has almost 500-550 ha of organic rainfed olive groves distributed in isolated plots $[24,35,38]$. Assuming that organic management constitutes an agrarian model towards which the crops of the study area can be transferred, thus responding to the existing political and social demands, the study presented two specific objectives: (a) to characterise the organic olive grove of the PDO Estepa edaphologically and to quantify the multidimensional impacts (i.e., environmental, socio-economic and productive) derived from erosive processes, and (b) to carry out an analysis of the sustainability and durability of this olive grove management on the basis of long-term simulations of farm production and profitability.

\section{Materials and Methods}

\subsection{Study Area}

The study area corresponds to the PDO Estepa, in Seville (Andalusia, Southern Spain) (Figure 1).

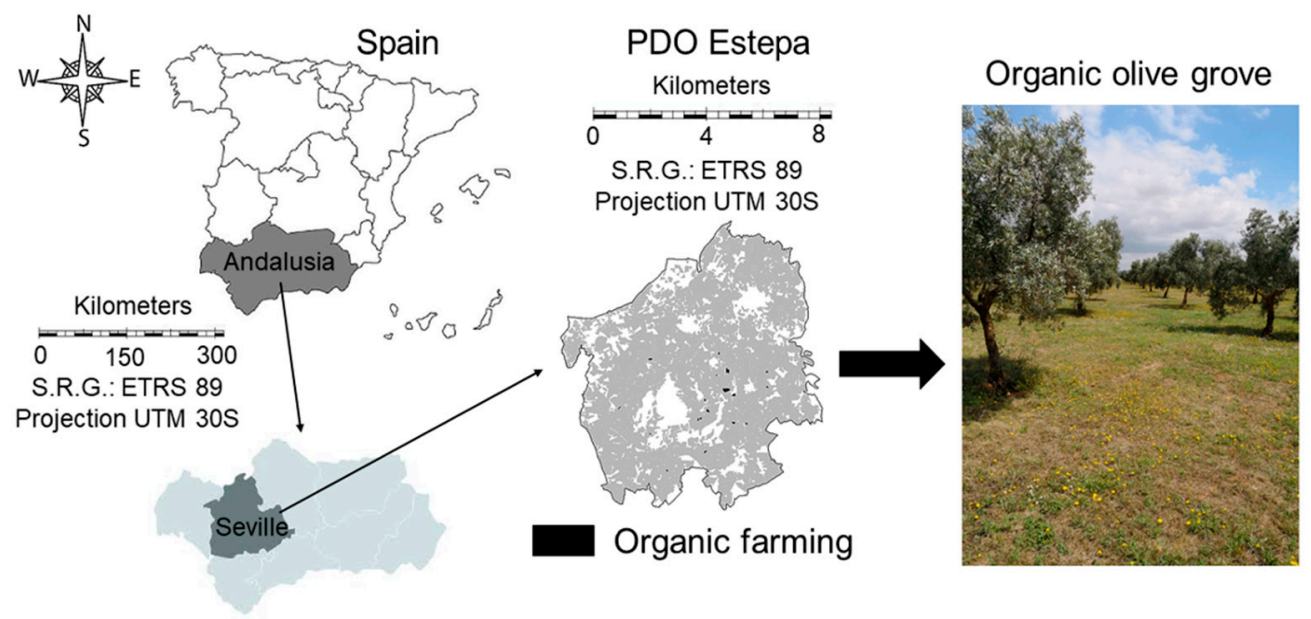

Figure 1. Geographical location of the PDO Estepa in Seville (Andalusia, Spain), highlighting the organic management of the olive grove in this region.

Estepa region was constituted as a denomination of origin (DO) at the national level in 2004, being recognised by the Andalusian Regional Government and the Ministry of Agriculture, Fisheries and the Environment [39]. Subsequently, in 2010 it was recognised as 
a protected designation of origin (PDO) at the European level, leading to greater recognition and enhancement of its food products (i.e., olive oil and table olives) [39,40]. This region, where agriculture is highly developed and extensive as monocultures, has 39,694 ha of olive groves together with another 20,000 ha of native vegetation $[9,36,39]$. This PDO is characterised by a continental Mediterranean climate, where the average temperature is between $17-18{ }^{\circ} \mathrm{C}$, and the average annual rainfall is $477 \mathrm{~mm}[24,35,41]$. Specifically, olive groves are located on geologically calcareous soils, with loams and clays, of variable depths (i.e., 30-150 cm), being predominantly loamy textured environments with few edaphic aggregates that contribute to increasing their stability $[42,43]$. Thus, the predominant soil types in this region are of the Albariza type, with a low water retention capacity and a high susceptibility to laminar erosion processes, causing gullies on farms [14,42]. Olive groves are therefore located at altitudes ranging from 200-800 $\mathrm{m}$ above sea level (masl), where the $\mathrm{pH}$ is predominantly alkaline, with values of up to $8.62[9,43]$.

In the Estepa region, olive groves have two different management models. Thus, the majority of the olive-growing area belonging to this PDO is under a rainfed and integrated management, with a minority of plots with deficit/drip irrigation (i.e., adding water to the crop only in times of water stress and with a limit of up to $1500 \mathrm{~m}^{3} \mathrm{ha}^{-1}$ ) $[44,45]$. Under this management, where the use of chemical fertilisers is allowed in a controlled way, olive groves have a planting density of 100-500 trees ha ${ }^{-1}$ and a productive yield of 350-900 L of olive oil ha ${ }^{-1}[9,40,46]$. In addition, it is worth highlighting the relevance of the organic olive grove as a second management model in the PDO Estepa, considering its analysis is the main objective of this research. Organic olive groves are novel in the study area, and only 500 ha of olive groves are certified organic [24,39,40,43]. However, there is a trend towards the adoption of this management model in Andalusia and Estepa regions, and it is foreseeable that its representativeness will increase in the near future $[17,29,32]$. In this management, olive groves present a planting density of approximately 200 trees ha $^{-1}$, with an average production of $700 \mathrm{~L}$ of olive oil ha ${ }^{-1}[9,40]$. As general characteristics of this agrarian model, it should be specified that, although it is possible to implement deficit irrigation in organic olive groves, in the study area there is a predominance of rainfed management in these farms [24,40]. Additionally, in this management, only organic fertilisers are used together with biological and integrated mechanisms, such as pest control measures, which highlights the use of organic phytosanitary products based on previous analyses of leaf, soil, and water quality in farms, and the use of auxiliary fauna as a biological predator of harmful pests in the olive grove $[9,30,47]$. Thus, by not using chemical agents in organic agriculture, the risk of diffuse pollution is reduced, increasing the environmental quality of farms, and the production of safety food products is promoted (considered one of the greatest demands of society towards agriculture [31,32]), thus avoiding the possible damaging consequences of the consumption of contaminated products by consumers $[29,30,34,35]$.

\subsection{Experimental Design and Data Collection}

In order to ensure that the samples collected were representative at the PDO Estepa level, a stratified sampling design of the study area was carried out according to the erosive states of the territory and olive grove management, where only organic plots were considered as sampling units. Based on the use of cadastral and land use databases [48,49], Estepa region was classified into different erosive states. The erosion levels identified from the mapping used were classified on the basis of the Moreira-Madueño criterion [50], which establishes 4 erosive categories in agricultural soils (i.e., null, slight, moderate and severe erosion). Additionally, by applying the universal soil loss equation (i.e., USLE model, Equation (1)), the annual laminar type water erosion along the study area was quantified [51,52].

$$
\mathrm{A}=\mathrm{R} \times \mathrm{K} \times \mathrm{LS} \times \mathrm{C} \times \mathrm{P}
$$


where A: annual erosion $\left(\mathrm{t} \mathrm{ha}^{-1}\right.$ year $\left.^{-1}\right)$; R: rain erosivity $\left(\mathrm{J} \mathrm{ha}^{-1}\right)$; K: soil erodibility $\left(\mathrm{Mg} \mathrm{J}^{-1}\right)$; LS: length and degree of slope (dimensionless and in \%); C: ground cover (dimensionless); P: agricultural conservation practices (dimensionless).

Following the methodology described in previous studies published for the PDO Estepa $[24,35,36,38,43,46]$, the USLE equation was calibrated specifically for the organic olive grove in this region, taking into account the soil, climatological and agricultural characteristics of the study area. In this sense, rain erosivity (i.e., $\mathrm{R}$ factor), and the degree and length of the slope of the territory (i.e., LS factor) were estimated and calibrated according to scientific and technical literature references, specific to the study area $[9,53,54]$. Soil erodibility (i.e., $\mathrm{K}$ factor) was calculated experimentally and empirically, following the criteria of Gisbert Blanquer et al. [55], where soil texture and structure, organic matter content and soil permeability are taken into account, data previously published by Rodríguez Sousa et al. [36]. Ground cover (i.e., C factor) was calibrated according to the criteria of Gómez et al. [56]. Thus, C factor is intrinsically dependent on the structural characteristics of the crop, with tree density, tree canopy diameter and the extent of plant covers in the plots being conditioning factors. In this sense, tree density is low in organic (200 trees $\mathrm{ha}^{-1}$ ) an integrated olive grove managements, being maximum at intensive or highly-intensive orchards. Additionally, organic olive groves of the PDO Estepa are olive groves converted from integrated agriculture, so they retain the structural characteristics of such management, with trees having a radius of $2.5 \mathrm{~m}$ at the canopy. Lastly, unlike the integrated olive grove, the organic management of the study area has living or inert plant covers throughout the year. Bearing in mind the characteristics of the organic plots described above, this management acquired, according to Gómez et al. [56], a value of 0.06 for $\mathrm{C}$ factor. Finally, for the agricultural conservation practices (i.e., $\mathrm{P}$ factor), was assumed, according to the Sánchez Escobar and Rodríguez Sousa et al. criteria previously considered for the study area $[36,46,54]$, a constant value of 1 for all erosion levels, due to the fact that all farms are subject to tillage practices. Table 1 shows the results corresponding to the quantification of soil loss for the study area.

Table 1. Estimation of soil erosion $\left(\mathrm{A}, \mathrm{t} \mathrm{ha}^{-1}\right.$ year $\left.^{-1}\right)$ for the organic olive groves in the PDO Estepa according the USLE equation. Units of factors R and $\mathrm{K}$ are in parentheses. The LS, C, and P factors are dimensionless (LS factor is also expressed as a percentage).

\begin{tabular}{|c|c|c|c|c|c|c|c|}
\hline \multirow{2}{*}{ Management } & \multirow{2}{*}{ Erosion Level } & \multicolumn{5}{|c|}{ Factors } & \multirow{2}{*}{$\begin{array}{c}\mathrm{A} \\
\left(\mathrm{t} \mathrm{ha}^{-1} \text { year }^{-1}\right)\end{array}$} \\
\hline & & $R\left(\mathrm{~J} \mathrm{ha}^{-1}\right)$ & $\mathrm{K}\left(\mathrm{Mg} \mathrm{J}^{-1}\right)$ & LS & $\mathrm{C}$ & $\mathbf{P}$ & \\
\hline \multirow{2}{*}{ Organic } & Null & 109.70 & 0.82 & $0.00(0 \%)$ & 0.06 & 1.00 & - \\
\hline & Moderate & 109.70 & 0.56 & $0.70(7 \%)$ & 0.06 & 1.00 & 2.58 \\
\hline
\end{tabular}

After estimating the erosion levels in the study area, it was observed, in line with previous studies [24], that organic olive groves existed only in areas with null or moderate erosion. Taking into account the novel nature of organic groves in the PDO Estepa as a limitation of this research, it should be noted that there are currently only 19 isolated plots with this type of agricultural management. Thus, all existing plots were sampled (i.e., 9 plots with null erosion and 10 plots with moderate erosion), obtaining a final sample size of $n=19$ plots (Figure 2). 


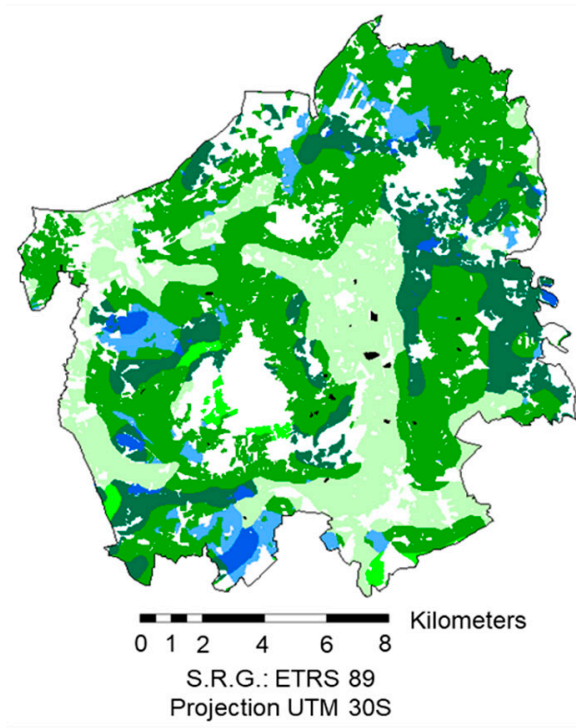

Areas without olive groves

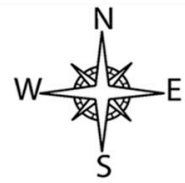

(a) Integrated farming

Rainfed olive groves with null erosion

Rainfed olive groves with slight erosion

Rainfed olive groves with moderate erosion

Rainfed olive groves with severe erosion

Irrigated olive groves with moderate erosion

Irrigated olive groves with severe erosion

(b) Organic farming

Organic olive grove plots with null and

moderate erosion. Sampling points

Figure 2. Sampling design carried out in the PDO Estepa. The classification of the territory is shown in terms of its erosion levels (i.e., null, slight, moderate, and severe), and with respect to the existing farm managements, where rainfed and irrigated integrated olive groves represent the majority of the territory. Additionally, isolated plots of organic olive groves can be observed, coinciding with the sampling points.

\subsubsection{Data on the Environmental Dimension of the Olive Grove}

Based on specific bibliography and on data published in previous research carried out on the PDO Estepa, soil depth, soil weight, and dry bulk density values were acquired, as well as soil texture using the Bouyoucos method, resulting from the estimation of the concentration of sands, silts and clays in the sampled territory $[9,40,43,46,49,50]$. Similarly, published data were also obtained on the gravel content of the organic olive grove, its porosity, moisture, $\mathrm{pH}$ and edaphic potassium concentration [24,43]. In order to complete the soil characterisation already carried out for organic olive groves in the PDO Estepa, the existence of statistical differences between these variables according to the erosion of the territory was checked. Additionally, a $1 \mathrm{~km}$ long and $5 \mathrm{~m}$ wide transect was established in each plot to estimate different environmental variables (i.e., edaphic and biological) to observe the influence of erosion (i.e., null or moderate) on the crop.

From an edaphic perspective, 3 equidistant soil samples were collected in each transect. After processing the samples (i.e., drying for $24 \mathrm{~h}$ at $105^{\circ} \mathrm{C}$ ), they were sieved through a $2 \mathrm{~mm}$ mesh to obtain the fine fraction of the soil. From the sieved samples, soil fine fraction was calculated (i.e., silts plus clays). Soil aeration was also quantified as a structural edaphic parameter [57], through the difference between the values of porosity and moisture previously consulted in specific bibliography [43] (Equation (2)).

$$
\text { Aeration }=\text { Porosity }- \text { Moisture }
$$

where Aeration: amount of soil pores with air (\%); Porosity: amount of soil pores (\%); Moisture: amount of soil pores with water (\%).

As indicators of soil fertility and enzyme activity, soil carbon concentration (\%) was estimated using a colourimetric method [58], and through similar methodologies, the edaphic concentration of $\beta$-glucosidase ( $\mu \mathrm{mol}$ p-nitrophenol $\mathrm{gr}^{-1} \mathrm{~h}^{-1}$ ) and phosphatase ( $\mu$ mol p-nitrophenol $\mathrm{gr}^{-1} \mathrm{~h}^{-1}$ ) was quantified [59]. $\mathrm{pH}$ values were complemented by estimating soil conductivity $\left(\mu \mathrm{S} \mathrm{cm}{ }^{-1}\right)$. Phosphate and nitrate concentrations (ppm) were estimated using colorimetric methods, being indicators of diffuse contamination $[60,61]$.

Biologically, taking into account the erosion level of the plots, 10 squares of $25 \mathrm{~cm}$ side $^{-1}$ were arranged along each transect to quantify the average plant cover and bare soil in the sampled groves (i.e., 10 samples plot $^{-1}$ ). The richness of specific plant species that 
act as mitigating agents of erosion processes, such as legumes, grasses and crucifers plants, was also quantified (number of species) [62]. Finally, plant diversity of organic olive groves was estimated using Shannon Index and Simpson's Index as dominance indicator, where values close to 1 will indicate a high dominance of a particular species, and values close to 0 will reflect a higher plant evenness $[63,64]$ (Equations (3) and (4)).

$$
\mathrm{H}^{\prime}=-\Sigma \mathrm{p}_{\mathrm{i}} \times \log _{2} \mathrm{p}_{\mathrm{i}}
$$

where $\mathrm{H}^{\prime}$ : Shannon diversity value (bits); $\mathrm{p}_{\mathrm{i}}$ : relative abundance of each species.

$$
\mathrm{D}=1-\Sigma \mathrm{p}_{\mathrm{i}}^{2}
$$

where D: plant dominance (0-1); $\mathrm{p}_{\mathrm{i}}$ : proportional abundance of species $\mathrm{i}$ (number of individuals of species $i$ on the total number of individuals in the sample).

\subsubsection{Data on the Productive and Socio-Economic Dimensions of the Olive Grove}

In each sampling plot with organic olive groves in the PDO Estepa ( $n=19$ plots), a survey was carried out with each owner in order to collect economic-productive and social information on the study area corresponding to the average of the 2017 and 2018 seasons, taking into account the different erosion levels (i.e., null or moderate) between the farms. Through these surveys, information was collected on: (a) farm structure: plot size (ha), plant density (trees ha ${ }^{-1}$ ), and productive yield ( $\mathrm{kg}$ olives ha ${ }^{-1}$ and L of olive oil ha ${ }^{-1}$ ); (b) economic parameters: farm income $\left(€ \mathrm{ha}^{-1}\right)$, subsidies received through the common agricultural policy (CAP) $\left(€ \mathrm{ha}^{-1}\right.$ year $\left.^{-1}\right)$, selling price at origin per $\mathrm{kg}$ of olives and per $\mathrm{L}$ of oil ( $€ \mathrm{~kg}^{-1}$ or $€ \mathrm{l}^{-1}$ ), and farm costs (personnel, machinery and organic inputs, $€ \mathrm{ha}^{-1}$ year $^{-1}$ ); (c) social indicators: labour force (persons year ${ }^{-1}$ ); and (d) degree of satisfaction with organic olive grove management, presence or absence of organic certification, and willingness to change agricultural management in the future.

Through the average data, differences between the erosion levels were tested. Using Stella 9.1.4 software [65], 150-year projections were made to estimate the productive and economic sustainability of the olive grove taking into account the influence of erosion on production, being a reasonable time that responds to the short-term demands of farmers regarding the management of their plots $[2,10,20,26,56]$. This sustainability was estimated per ha of farm using the criteria of Rodríguez Sousa et al. [36,46] to simulate the loss of production due to erosion over time specifically for the study area (Equation (5)).

$$
\operatorname{Production}_{(\mathrm{t})}=\mathrm{P}_{\mathrm{i}} \times\left(\mathrm{c}_{1}+\mathrm{c}_{2} \times \ln \left(\mathrm{W}_{\mathrm{j}}-\mathrm{Er}_{\mathrm{j}} \times \mathrm{t}\right)+\mathrm{c}_{3} \times\left(\ln \left(\mathrm{W}_{\mathrm{j}}-\mathrm{Er}_{\mathrm{j}} \times \mathrm{t}\right)\right)^{2}\right),
$$

where Production $_{(t)}$ : production of the management $\mathrm{i}$ at time $\mathrm{t}\left(\mathrm{t}\right.$ ha $\left.{ }^{-1}\right) ; \mathrm{c}_{1}, \mathrm{c}_{2}$, and $\mathrm{c}_{3}$ : constants of the study area dependent on annual precipitation and soil type, being 0.7388 , -0.3471 and 0.0401 respectively; $\mathrm{P}_{\mathrm{i}}$ : initial production $(\mathrm{t}=0)$ of the management $\mathrm{i}\left(\mathrm{t} \mathrm{ha}^{-1}\right)$; $\mathrm{Wj}$ : weight of soil corresponding to the erosive state $\mathrm{j}\left(\mathrm{t} \mathrm{ha}^{-1}\right)$; Erj: erosion rate proper to the erosive state $\mathrm{j}\left(\mathrm{t} \mathrm{ha}^{-1}\right.$ year $^{-1}$ ); $\mathrm{t}$ : simulation time (years).

Equation (5) was calibrated on the basis of the data collected, taking into account the following assumptions: (a) the annual yield to obtain $1 \mathrm{~L}$ of olive oil from olive harvest ranges between 18-21\%, taking an average yield of 19\% (i.e., $5.26 \mathrm{~kg}$ of olives are needed to produce $1 \mathrm{~L}$ of olive oil) [16,46]; and (b) a production limit of $1500 \mathrm{~kg}$ olive ha ${ }^{-1}$ or $300 \mathrm{~L}$ of olive oil was considered, assuming the abandonment of farms with a production below this threshold $[36,66]$. Accumulated production and profitability per hectare of organic olive grove were calculated over time simulation, according to their erosion level.

\subsection{Statistical Methodology}

According to the experimental design carried out, we had a single factor (i.e., organic olive grove) with two independent treatments (i.e., null and moderate erosion), and several dependent variables. To know how these data were distributed, normality and homoscedas- 
ticity were tested by means of a Shapiro-Wilk and Levene tests (null hypothesis $\left(\mathrm{H}_{0}\right)$ : data come from normal and homoscedastic populations; alternative hypothesis $\left(\mathrm{H}_{1}\right)$ : data are not normal and heteroscedastic) [67]. To determine the possible existence of statistically significant differences for the dependent variables between the erosion levels (i.e., two treatments), a comparison of means based on Student's T-test was performed for normal and homoscedastic variables, contrasting the equality of means $\left(\mathrm{H}_{0}\right)$ against the alternative hypothesis on the difference between means (i.e., $\mathrm{H}_{0}: \mu_{1}=\mu_{2} ; \mathrm{H}_{1}$ : not certain $\mathrm{H}_{0}$ ) [67]. On the other hand, a Mann-Whitney U-rank test was used for non-parametric variables, testing the null hypothesis of equality of medians, against the alternative hypothesis regarding their differences (i.e., $\mathrm{H}_{0}: \mathrm{m}_{1}=\mathrm{m}_{2} ; \mathrm{H}_{1}$ : not certain $\mathrm{H}_{0}$ ) $[68,69]$. It should be noted that since there were only two treatments, it is not necessary to perform a post-hoc test for significant differences in a variable, as their identification is straightforward. Following the same methods, the differences in accumulated production and profitability data between organic olive groves with null and moderate erosion were also tested. Statistical analyses were carried out using RStudio and SPSS software, through car library and MASS and PMCMRplus packages, using a significance level of $\alpha=0.05$ ( $p$-values: $p>0.05$ (non-significant differences), $p<0.05^{*}$ (significant differences), $p<0.01 * *$ (very significant differences), $p<0.001^{* * *}$ (highly significant differences) [70-72].

\section{Results}

3.1. Influence of Erosion on Environmental Dimension in Organic Olive Groves in the PDO Estepa

\subsubsection{Previous Edaphic Results}

Table 2 summarises the soil results previously published by Rodríguez Sousa et al. [43], analysing the significant differences for each variable between the erosive states. Statistically, all variables presented a normal and homoscedastic distribution, with non-significant $p$-values $(p>0.05)$ in the Shapiro-Wilk and Levene tests. Only the variables corresponding to the clay and gravel content in the soil showed a non-normal and heteroscedastic distribution, obtaining highly significant $p$-values $\left(p<0.001^{* * *}\right)$, thus rejecting the null hypothesis of normality and equality of variances. According to these results, to determine the existence of possible significant differences between these variables and erosion levels, a Student's T-test was executed for the parametric variables, and a Mann-Whitney U-test was used for clays and gravels.

Table 2. Mean (x) and standard deviation (SD) for the physico-chemical variables, specifying their units, in the organic olive grove of the PDO Estepa estimated in previous studies. The $p$-values about the means or medians comparison test performed between the erosion levels are also attached.

\begin{tabular}{|c|c|c|c|}
\hline \multirow{2}{*}{ Variable (Unit) } & \multicolumn{2}{|c|}{ Organic Olive Groves } & \multirow{2}{*}{$p$-Value } \\
\hline & Null Erosion $(x \pm S D)$ & Moderate Erosion $(x \pm S D)$ & \\
\hline Dry bulk density $\left(\mathrm{g} \mathrm{cm}^{-3}\right)$ & $1.05 \pm 0.02$ & $1.14 \pm 0.03$ & $<0.001 * * *$ \\
\hline Soil depth (cm) & $154.03 \pm 1.12$ & $119.70 \pm 1.01$ & $<0.001^{* * *}$ \\
\hline Soil weight $\left(\mathrm{t} \mathrm{ha}{ }^{-1}\right)$ & $16,173.15 \pm 322.19$ & $13,645.80 \pm 154,37$ & $<0.001 * * *$ \\
\hline Gravel (\%) & $15.73 \pm 0.53$ & $4.06 \pm 0.08$ & $<0.001 * * *$ \\
\hline Sands $(\%)$ & $46.75 \pm 0.09$ & $49.40 \pm 0.07$ & $<0.001 * * *$ \\
\hline Silts (\%) & $40.84 \pm 0.03$ & $30.95 \pm 0.01$ & $<0.001^{* * *}$ \\
\hline Clays (\%) & $12.41 \pm 0.07$ & $19.65 \pm 0.06$ & $<0.01 * *$ \\
\hline Porosity $(\%)$ & $68.96 \pm 0.17$ & $66.05 \pm 0.12$ & $<0.001^{* * *}$ \\
\hline Moisture (\%) & $24.73 \pm 0.21$ & $23.42 \pm 0.17$ & $<0.001 * * *$ \\
\hline $\mathrm{pH}($ (一) & $8.60 \pm 0.02$ & $8.21 \pm 0.02$ & $<0.001^{* * *}$ \\
\hline Potassium $\left(\mathrm{mg} \mathrm{kg}^{-1}\right)$ & $168.58 \pm 3.48$ & $161.32 \pm 2.64$ & $<0.001^{* * *}$ \\
\hline Soil texture $(-)$ & Loam & Loam & - \\
\hline
\end{tabular}

*** highly significant differences, ${ }^{* *}$ very significant differences. 
The results showed that the level of erosion of the plots was a determining factor in the edaphic properties, with highly significant differences being detected in all the variables analysed $\left(p<0.001^{* *}\right)$, except for the clay content, where the differences found were very significant $\left(p<0.01^{* *}\right)$. In general terms, the increase in erosion caused the formation of more compacted soils, resulting in an increase of $8.57 \%$ in dry bulk density. On the other hand, the most eroded plots showed a $22.29 \%$ and $15.63 \%$ loss in soil depth and soil weight, respectively. No textural differences were observed, with a predominantly loam soil texture, however, sands and clays content increased by $5.67 \%$ and $58.34 \%$ in the most eroded plots, while silt concentration decreased by $24.22 \%$. Similarly, the gravel content decreased by $74.19 \%$ in the plots with moderate erosion, this variable being a mitigating agent of erosion processes. Structurally, the increase in the magnitude of erosive processes caused a slight decrease in soil porosity of $4.22 \%$, related to the increase in soil compaction, together with a decrease in soil moisture (i.e., decrease $5.30 \%$ ). From a chemical point of view, the plots with less erosion had $\mathrm{pH}$ values up to $4.75 \%$ higher, being more basic soils. Finally, edaphic potassium concentration decreased by $4.50 \%$ as the erosive magnitude of the sampled farms increased.

\subsubsection{Original Soil and Biological Variables}

To complete the soil characterisation carried out in previous studies, Table 3 shows the original results obtained for different soil parameters in organic olive groves of the PDO Estepa. According to the Shapiro-Wilk and Levene tests, all variables showed a normal and homoscedastic distribution $(p>0.05)$, and a parametric test for comparison of means (i.e., Student's T-test) could be performed. Only the content of fine fractions, $\beta$-glucosidase and phosphatase showed a non-normal and heteroscedastic behaviour $\left(p<0.05^{*}\right)$, using in these cases a median comparison test (i.e., Mann-Whitney U-test).

Table 3. Mean (x) and standard deviation (SD) for the new soil parameters sampled, specifying their units, in organic olive groves in the PDO Estepa. It is also attached the $p$-values according to the to the mean or medians comparison test performed between the erosion levels.

\begin{tabular}{|c|c|c|c|}
\hline \multirow{2}{*}{ Variable (Unit) } & \multicolumn{2}{|c|}{ Organic Olive Groves } & \multirow{2}{*}{$p$-Value } \\
\hline & Null Erosion $(x \pm S D)$ & Moderate Erosion $(x \pm S D)$ & \\
\hline Fine fractions $(\%)$ & $53.36 \pm 0.10$ & $46.90 \pm 1.24$ & $<0.001^{* * *}$ \\
\hline Aeration (\%) & $44.26 \pm 0.17$ & $42.62 \pm 0.11$ & $<0.001^{* * *}$ \\
\hline Carbon in soil (\%) & $2.26 \pm 0.03$ & $1.55 \pm 0.01$ & $<0.001^{* * *}$ \\
\hline $\begin{array}{c}\text { B-glucosidase } \\
\left(\mu \mathrm{mol} p \text {-nitrophenol gr }{ }^{-1} \mathrm{~h}^{-1}\right)\end{array}$ & $1.07 \pm 0.09$ & $2.30 \pm 0.25$ & $<0.001^{* * *}$ \\
\hline $\begin{array}{c}\text { Phosphatase } \\
\left(\mu \mathrm{mol} p \text {-nitrophenol gr }{ }^{-1} \mathrm{~h}^{-1}\right)\end{array}$ & $0.29 \pm 0.03$ & $1.01 \pm 0.05$ & $<0.001^{* * *}$ \\
\hline Conductivity $\left(\mu \mathrm{S} \mathrm{cm}^{-1}\right)$ & $182.44 \pm 9.48$ & $227.05 \pm 10.81$ & $<0.001^{* * *}$ \\
\hline Phosphates (ppm) & $0.12 \pm 0.04$ & $0.44 \pm 0.06$ & $<0.001^{* * *}$ \\
\hline Nitrates (ppm) & $2.89 \pm 0.33$ & $3.79 \pm 0.20$ & $<0.001^{* * *}$ \\
\hline
\end{tabular}

*** highly significant differences.

Results showed highly significant differences $\left(p<0.001^{* * *}\right)$ for all dependent variables between the two erosion levels sampled. Thus, an increased representativeness of up to $12.11 \%$ of the fine soil fractions in non-eroded soils, together with increased aeration (i.e., up to an additional 3.71\%) was observed. The higher erosion resulted in a decrease of $31.42 \%$ in soil carbon accompanied by an increase in soil enzyme activity (i.e., increases of $114.95 \%$ and $248.27 \%$ for $\beta$-glucosidase and phosphatase). Similarly, the greater magnitude of erosion processes was related to an increase of up to $23.10 \%$ in soil conductivity, with the most eroded soils showing a higher phosphate and nitrate content (increases of $266.66 \%$ and $31.14 \%$, respectively).

Additionally, new biological variables were measured, completing the environmental perspective of organic olive groves. Table 4 summarises these results. Following the same statistical protocol as described for the edaphic parameters, these data were normal 
and homoscedastic $(p>0.05)$, running a Student's T-test. However, the species richness (i.e., legumes, grasses, and crucifers), and Simpson's index, were non-parametric variables according to the Shapiro-Wilk and Levene tests $\left(p<0.001^{* * *}\right)$, using a Mann-Whitney U test to test for significant differences between the treatments.

Table 4. Mean (x) and standard deviation (SD) for the new biological variables sampled in the organic olive grove in the PDO Estepa. The unit of each variable is indicated (sps: number of species). It is also shown the $p$-values regarding the mean or medians comparison test performed between the erosion levels.

\begin{tabular}{cccc}
\hline \multirow{2}{*}{ Variable (Unit) } & \multicolumn{2}{c}{ Organic Olive Groves } & $p$-Value \\
\cline { 2 - 3 } & Null Erosion (x \pm SD) & Moderate Erosion (x \pm SD) & $<0.001^{* * *}$ \\
\hline Plant cover (\%) & $71.91 \pm 0.62$ & $43.55 \pm 0.39$ & $<0.001^{* * *}$ \\
\hline Bare soil (\%) & $28.09 \pm 0.62$ & $56.45 \pm 0.39$ & $<0.001^{* * *}$ \\
\hline Legume richness (sps) & $2.32 \pm 0.52$ & $0.98 \pm 0.78$ & $<0.001^{* * *}$ \\
\hline Grass richness (sps) & $2.73 \pm 0.52$ & $0.67 \pm 0.51$ & $<0.001^{* * *}$ \\
\hline Crucifers richness (sps) & $2.56 \pm 0.50$ & $0.00 \pm 0.00$ & $<0.05^{*}$ \\
\hline Shannon Index (H', bits) & $2.15 \pm 0.06$ & $2.05 \pm 0.07$ & $>0.05$ \\
\hline $\begin{array}{c}\text { Simpson's Index } \\
\text { (D, dimensionless) }\end{array}$ & $0.84 \pm 0.07$ & $0.82 \pm 0.03$ & \\
\hline
\end{tabular}

*** highly significant differences, ${ }^{*}$ significant differences.

The data obtained showed the existence of highly significant $\left(p<0.001^{* * *}\right)$ and significant $\left(p<0.05^{*}\right)$ differences in all the analysed variables, with the exception of Simpson's index, whose results were similar in both erosion levels, reaching values close to 1 , suggesting the existence of few dominant plant species in the ecosystem. A higher herbaceous cover was observed in the plots with null erosion, but decreased by $39.44 \%$ as the erosion of the land increased. Conversely, the percentage of bare soil on the farms sampled increased with erosion by $100.96 \%$. Additionally, the quantified richness of legumes, grasses and crucifers decreased with erosion by $57.76 \%, 75.46 \%$ and to 0 species respectively. Specifically, the richest dominant plants in the farms sampled were Vicia sativa (L., 1753) as legume, Festuca rubra (L., 1753) as grass, and Sinapsis alba (L., 1753) as cruciferous. Finally, plant diversity values, estimated according to the Shannon Index, were higher in plots with no erosion, decreasing by $4.65 \%$ in plots with moderate erosion.

3.2. Productive and Socio-Economic Original Results According to the Erosion Level in Organic Olive Groves in the PDO Estepa

This subsection shows the results corresponding to two different dimensions of olive groves, the productive dimension and the socio-economic dimension.

Firstly, the main structural and productive data collected on the basis of owner surveys on organic olive groves in the Estepa region are summarised in Table 5. All these data were non-normal and heterocedastic according to Shapiro-Wilk and Levene tests (i.e., $p<0.001^{* * *}$ ), and a median comparison test (i.e., Mann Whitney U rank test) had to be run to assess the possible existence of significant differences according to erosion levels.

Table 5. Mean (x) and standard deviation (SD) for productive variables, specifying their units, in the organic olive grove of the PDO Estepa. The $p$-values regarding the means or medians comparison test performed between the erosion levels are also attached.

\begin{tabular}{|c|c|c|c|}
\hline \multirow{2}{*}{ Variable (Unit) } & \multicolumn{2}{|c|}{ Organic Olive Groves } & \multirow{2}{*}{$p$-Value } \\
\hline & Null Erosion $(x \pm S D)$ & Moderate Erosion $(x \pm S D)$ & \\
\hline Plot size (ha) & $7.63 \pm 2.78$ & $3.00 \pm 1.17$ & $<0.05 *$ \\
\hline Plant density (trees ha ${ }^{-1}$ ) & $277.67 \pm 36.48$ & $384.95 \pm 29.90$ & $<0.05^{*}$ \\
\hline Productive yield (kg olive $\mathrm{ha}^{-1}$ ) & $2708.08 \pm 3.50$ & $3613.04 \pm 96.02$ & $<0.001^{* * *}$ \\
\hline Productive yield (l olive oil ha ${ }^{-1}$ ) & $514.84 \pm 0.66$ & $686.88 \pm 18.25$ & $<0.001^{* * *}$ \\
\hline
\end{tabular}


Significant $\left(p<0.05^{*}\right)$ and highly significant $\left(p<0.001^{* * *}\right)$ differences were found for the variables analysed. Plots with null erosion showed in general a larger area than those with moderate erosion (i.e., up to $60.68 \%$ more surface area). Thus, although the largest plots sampled were 25.65 ha and 17.29 ha under null and moderate erosion respectively, in general the organic olive groves were located in small, isolated plots. Plots with moderate erosion showed a higher plant density and, therefore, a higher productive yield per hectare, reaching production values up to $33.41 \%$ more than plots without erosion. However, it should be noted that if production per tree is analysed (i.e., yield per hectare divided by plant density), the yield is $3.80 \%$ higher in absence of erosion processes (i.e., $9.75 \mathrm{~kg}$ olive tree $^{-1}$ versus $9.38 \mathrm{~kg}_{\text {olive tree }}^{-1}$ ).

On the other hand, following the same methodology as for the surveys of organic plot owners in the study area, in Table 6 socio-economic data (i.e., including farmers perceptions and the existence of organic certification) are compiled for organic olive groves. Except for the variables referring to farm income and labour force, for which a Student's T-test was used, all data were non-parametric (i.e., $p<0.001^{* * *}$ in Shapiro-Wilk and Levene tests). Thus, a Mann-Whitney U rank test was used to check for the existence of significant differences in the variables according to erosion levels.

Table 6. Mean (x) and standard deviation (SD) for the socio-economic variables, specifying their units, in the organic olive grove of the PDO Estepa. The $p$-values regarding the means or medians comparison test performed between the erosion levels are also attached.

\begin{tabular}{|c|c|c|c|}
\hline \multirow{2}{*}{ Variable (Unit) } & \multicolumn{2}{|c|}{ Organic Olive Groves } & \multirow{2}{*}{$p$-Value } \\
\hline & $\begin{array}{l}\text { Null Erosion } \\
\quad(x \pm S D)\end{array}$ & $\begin{array}{l}\text { Moderate Erosion } \\
\quad(x \pm \text { SD })\end{array}$ & \\
\hline Farm income $\left(€ \mathrm{ha}^{-1}\right)$ & $1216.47 \pm 2.80$ & $1090.43 \pm 15.21$ & $<0.001 * * *$ \\
\hline Subsidies from CAP $\left(€\right.$ ha $^{-1}$ year $\left.^{-1}\right)$ & $299.50 \pm 0.00$ & $299.50 \pm 0.00$ & - \\
\hline Selling price at origin $\left(€ \mathrm{~kg}_{\text {olive }}{ }^{-1}\right)$ & $0.80 \pm 0.00$ & $0.80 \pm 0.00$ & - \\
\hline Selling price at origin $\left(€ \mathrm{~L}\right.$ olive oil $\left.{ }^{-1}\right)$ & $4.21 \pm 0.00$ & $4.21 \pm 0.00$ & - \\
\hline Farm costs $\left(€\right.$ ha $^{-1}$ year $\left.^{-1}\right)$ & $1249.50 \pm 0.00$ & $2099.50 \pm 0.00$ & $<0.001 * * *$ \\
\hline Labour force (persons year ${ }^{-1}$ ) & $107.00 \pm 0.69$ & $129.00 \pm 0.49$ & $<0.001^{* * *}$ \\
\hline Degree of satisfaction with organic management & High & High & - \\
\hline Organic certification & Yes & Yes & - \\
\hline Willingness to change the farm management & No & No & - \\
\hline
\end{tabular}

It was impossible to statistically test these differences for the subsidies received through the CAP (i.e., $229.50 € \mathrm{ha}^{-1}$ year $^{-1}$ ) and the sale prices at origin of the $\mathrm{kg}$ of olives and the $\mathrm{L}$ of olive oil (i.e., $0.80 € \mathrm{~kg}_{\text {olive }}{ }^{-1}$ and $4.21 € \mathrm{~L}_{\text {olive oil }}^{-1}$ ), as these values were constant in all the surveys implemented. Means or medians difference tests could not be carried out on the qualitative variables postulated (i.e., degree of satisfaction, existence of certified olive groves, and willingness to change the farm management). In this sense, all owners showed a high degree of satisfaction with the organic management, being certified, with no predisposition to change the agricultural management model on their plots in the short-medium term. Statistically, highly significant differences $\left(p<0.001^{* * *}\right)$ were found in the variables studied. In these sense, farm income was up to $10.36 \%$ higher on plots without erosion (i.e., null erosion). In a similar way, plots with moderate erosion showed more annual costs and labour force requirements, with higher values of up to $68.02 \%$ and $20.56 \%$, respectively.

\subsection{Time Projections and Cumulative Production and Benefits to Analyse Sustainability in Organic Olive Groves}

Based on the original results compiled in Tables 5 and 6 (i.e., productive yield, farm income, subsidies from CAP, selling price at origin, and farm costs) and following Equation (5) as a tool to simulate production loss due to erosion in the Estepa region, 
Figure 3 graphically summarises the results obtained for the 150-year projections of production and economic benefits, understood as the difference between income and costs, per hectare of organic olive groves at the respective levels of erosion in the PDO Estepa.

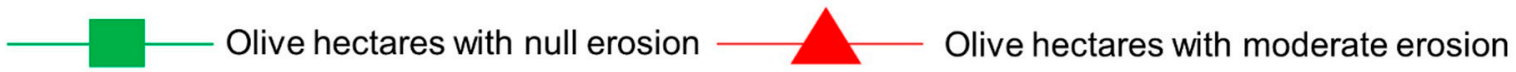

\section{(a) Production}
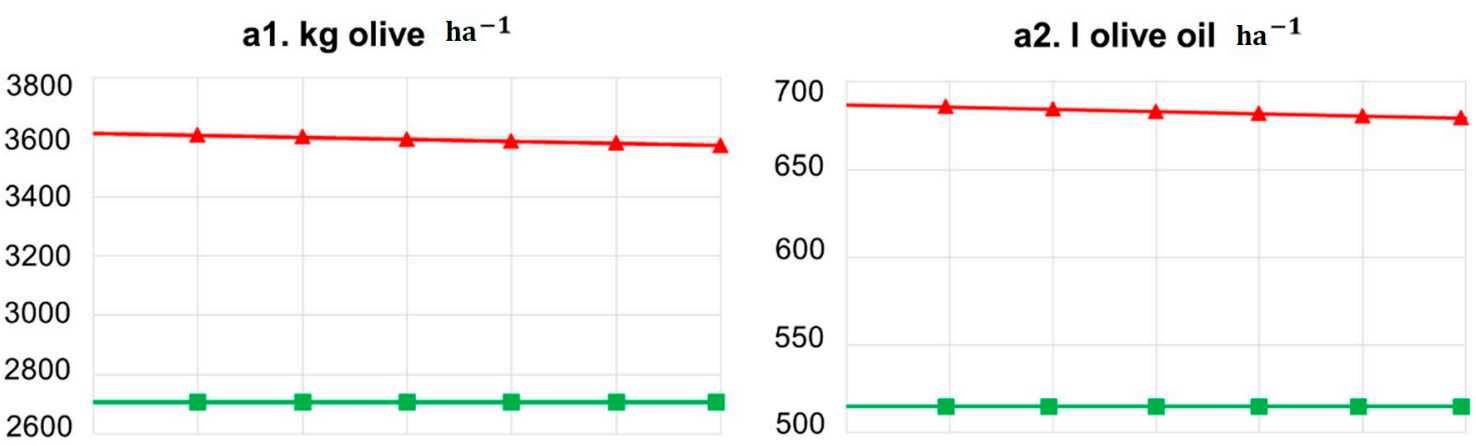

(b) Benefits $\left(€\right.$ ha $\left.^{-1}\right)$

b1. Without CAP

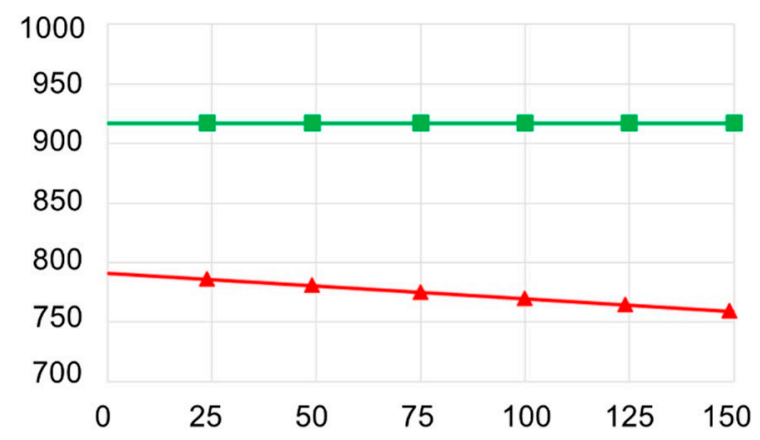

b2. With CAP

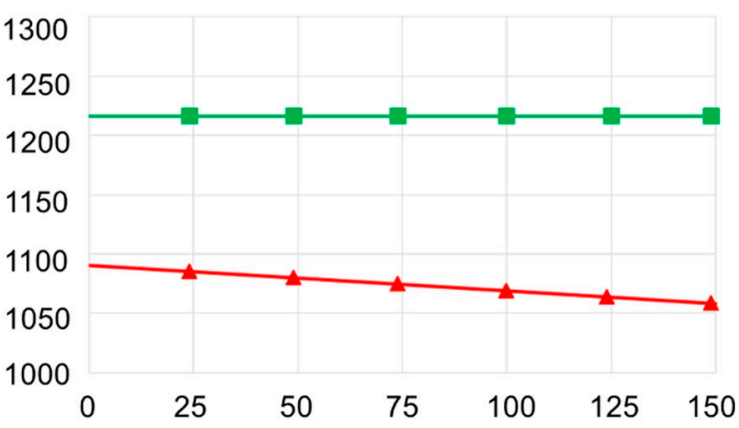

Years

Figure 3. Production per hectare (a), in kg of olives (a1) and L of olive oil (a2), for each erosion level in organic olive groves. The benefits per hectare (b) are also attached without considering CAP subsidies (b1) and incorporating them into the model (b2).

Throughout the simulation time, there was no drop in production below the threshold limit above which farm abandonment would be recommended at any level of erosion (i.e., $1500 \mathrm{~kg}$ olive ha ${ }^{-1}$ or $300 \mathrm{~L}$ olive oil ha ${ }^{-1}$ ), ensuring the productive and economic sustainability of the organic olive regardless of the erosion level. The productive yield per hectare of cultivated olive grove was higher in plots with moderate erosion, due to the higher plant density of these farms. However, in plots with null erosion, a stable production was observed throughout the projection, while in plots with high erosion a slight decrease in olive yield was observed due to the annual soil loss and its influence on agricultural production. On the other hand, olive grove plots without erosion showed higher economic benefits, while plots with moderate erosion showed a progressive downward trend with respect to their economic dimension, derived from the decrease in productivity due to the effect of erosion phenomena. Although the economic benefits were higher when CAP subsidies were taken into account, there was no change in their dynamics, with more benefits accruing to non-eroded plots. Thus, these subsidies constitute a constant value added to the income derived from agricultural activity.

Finally, on the basis of the results shown in Figure 3, where the sustainable character of the organic olive grove in the PDO Estepa is demonstrated, Table 7 provides the production and profit values (without and with CAP), per hectare, accumulated during the simulation 
time. These data were non-parametric according to the Shapiro-Wilk and Levene tests $\left(p<0.001^{* * *}\right)$, and a Mann-Whitney U test was carried out to check if there were significant differences for these variables between the erosion levels. Thus, highly significant differences $\left(p<0.001^{* * *}\right)$ were observed for the yields obtained in $\mathrm{kg}$ of olives and L of olive oil per hectare according the erosion level. This yield was up to $32.68 \%$ higher in the plots with moderate erosion, due again to the high plant density in these farms compared to the density of the plots without erosion. However, despite the higher cumulative productive yield of the plots with moderate erosion, their benefits were significantly lower $\left(p<0.05^{*}\right)$ by 15.49 without CAP subsidies and $11.68 \%$ when considering the CAP compared to the plots with null erosion, due to their higher annual costs of maintaining the olive crop.

Table 7. Production (in $\mathrm{kg}$ olive ha ${ }^{-1}$ and $\mathrm{L}$ olive oil ha ${ }^{-1}$ ), and benefits $\left(€ \mathrm{ha}^{-1}\right.$ ) without and with CAP accumulated in the simulation time (i.e., 150 years) for organic olive groves in their erosion levels.

\begin{tabular}{|c|c|c|c|}
\hline \multirow{2}{*}{ Variable (Unit) } & \multicolumn{2}{|c|}{ Organic Olive Groves } & \multirow{2}{*}{$p$-Value } \\
\hline & Null Erosion & Moderate Erosion & \\
\hline Production (kg olive ha $\left.{ }^{-1}\right)$ & 406,212 & 538,962 & $<0.001^{* * *}$ \\
\hline Production (L olive oil ha ${ }^{-1}$ ) & 77,227 & 102,464 & $<0.001 * * *$ \\
\hline Benefits without CAP $\left(€\right.$ ha $\left.^{-1}\right)$ & 137,545 & 116,245 & $<0.05^{*}$ \\
\hline Benefits with CAP $\left(€ \mathrm{ha}^{-1}\right)$ & 182,470 & 161,170 & $<0.05 *$ \\
\hline
\end{tabular}

\section{Discussion}

4.1. Influence of Erosion on the Environmental, Productive and Socio-Economic Dimensions of Organic Olive Grove Management in the PDO Estepa

Olive farming systems are Mediterranean systems, being landscape-shaping elements, especially in Southern Europe [1,2,12,18]. In Spain, Andalusia in particular, the representativeness of olive groves is maximised, as they provide ES to society and contribute to guaranteeing a stable welfare state $[11,19,73]$. However, many studies show the intrinsic vulnerability of these crops, as they are ecosystems that present multiple threats to their multifunctionality. Although there are economic (i.e., low farm income) and social threats (i.e., rural abandonment), which are particularly relevant in steep slope crops that can be classified as marginal due to their low yield, the most important threats to the viability of these systems are environmental [20,74]. These threats include microbial and entomological pests, which affect agricultural yields [75]; climate change, whose consequences on temperature and rainfall will have multiple impacts on the distribution area of olive groves [42,76]; diffuse pollution, derived from the use of chemical fertilisers [77]; and, particularly, laminar erosion, which is the main threat to olive sustainability, affecting the edaphic dimension of these crops, altering their agricultural production and economic benefits $[1,25-27,36,56]$.

Although erosion can have several impacts on agricultural systems, their intensity depends intrinsically on their magnitude. Previous studies carried out in the PDO Estepa have established a maximum erosion and soil loss per unit area of $36.68 \mathrm{t} \mathrm{ha}^{-1}$ year $^{-1}$ for integrated olive groves, which are partial plant covers $[9,24,36,46]$. However, this magnitude was reduced in organic plots, mainly due to the existence of total living plant covers that minimise the loss of soil materials on surface by runoff up to $75 \%$ [25,29]. Organic olive groves were only located, from a cartographic point of view, in areas whose slope responded to a null (i.e., LS factor of $0 \%$ ) or moderate (i.e., LS factor of $7 \%$ ) erosion level according to the Moreira-Madueño criterion [50], with a maximum soil loss rate of $2.58 \mathrm{tha}^{-1}$ year $^{-1}$. Although the intensity of erosion in organic plots was low, it was possible to evaluate its consequences on olive cultivation compared to non-eroded plots.

From an environmental perspective and in line with previous research, erosion in organic olive groves generated more compacted and less porous soils, hindering the root 
development of crops and plant covers as mitigating agents of erosion processes [43,46]. Similarly, soil depth and weight per unit area was lower in plots with greater erosion, due to the loss of soil horizons derived from this process $[25,26,56]$. Although no changes in the textural classification of soils in terms of erosion were observed, a higher content of gravels was showed in plots with null erosion, constituting a mitigating agent of erosive processes, avoiding runoff phenomena $[43,55]$. A lower content of edaphic fine particles (i.e., silts and clays) was also observed in plots with moderate erosion, resulting in soils with less stability due to the lack of edaphic aggregates that contribute to minimise soil loss [78]. Structurally, previous findings of higher soil moisture in plots without erosion were corroborated in this research, where soils with more humidity had a lower air pore content. Although low soil aeration can compromise gas diffusion and nutrient uptake by plants, following the criteria of Li et al. [79] and Ben-Noah and Friedman [80] the values measured in the study area were not a concern that could affect crop yields. Chemically, soils with moderate erosion were slightly more acidic, with a lower content of edaphic carbon, constituting less fertile environments for agriculture, negatively conditioning production over time $[58,78]$. A higher conductivity was also detected in crops with moderate erosion, due to the higher concentration of nitrates and phosphates in soil resulting from increased use of fertilisers to maintain a constant production output $[60,61,77]$. It should be noted that in organic farms, where only the use of non-chemical fertilisers is allowed, the nitrate and phosphate content detected, although it did not exceed the threshold established to be considered as contaminants, is due to the existence of diffuse pollution from nearby plots managed in an integrated way, where chemical fertilisers are used $[9,16,81]$. This higher concentration of these fertilisers resulted in higher soil enzyme activity, as there were no restrictions on the nutrients needed for microbial growth $[59,79]$. Finally, considering potassium as a cation asymptotically linked to agricultural production, its concentration decreased in moderately eroded plots, suggesting that, despite the higher production of these plots due to their higher plant density, the soil environment is less productive than non-eroded areas $[82,83]$.

On the other hand, the higher plant density in plots with moderate erosion resulted in higher productive yields. This measure aimed at mitigating the effects of erosion on the crop are linked to an increased need for labour force for olive harvesting, constituting a driving force for employment demand in the short term [24,35]. Economically, the selling prices at origin per $\mathrm{kg}_{\text {olive }} \mathrm{ha}^{-1}$ or $\mathrm{L}$ olive oil ha ${ }^{-1}$ were constant, showing values slightly higher than the selling price per $\mathrm{kg}_{\text {olive }} \mathrm{ha}^{-1}$ of integrated olive growing in the PDO Estepa according to Rodríguez Sousa et al. [46] criteria (i.e., 0.69-0.79 $€$ ha $^{-1}$ ). Although farm income showed values adjusted to farmers' demands on their standard of living [31,32], despite the higher production of moderately eroded plots their benefits were lower than those found in farms with null erosion, due to higher annual costs per hectare as the magnitude of erosion processes increased. These higher costs are due to the greater need to implement energy inputs (i.e., irrigation, fertilisers) to keep production constant for scenarios where erosion leads to a decrease in soil fertility and agricultural productivity $[8,10,19]$. Finally, landowners showed a high satisfaction with certified organic olive groves, with no willingness to modify the management of their plots in the shortmedium term, to benefit from the European subsidies granted by Pillar I and II of the current CAP (i.e., 2014-2020) towards agricultural managements that promote soil fertility together with rural development, objectives that will become more important in the post-2020 CAP, where a greater demand for agricultural multifunctionality rather than productivity will predominate $[33,34,84]$.

\subsection{Sustainability Assessment of the Organic Olive Grove in the PDO Estepa}

The assessment of agricultural sustainability, understood as the long-term economicproductive maintenance of crops without causing severe damage to nature and the environment, constitutes a complex challenge where holistic approaches based on the Triple Bottom Line (i.e., TBL), where the economic, social and environmental dimensions of these systems are evaluated $[85,86]$, must be applied. Although there are multiple lines of research that 
analyse the sustainability of agriculture from different perspectives, implementing the analysis of sub-indicators in multi-criteria decision-making analysis (i.e., MCDA) [23,24], or performing life cycle sustainability assessment of agrosystems (i.e., LCSA) [87,88], the present research has analysed the sustainability of organic olive groves in a specific region using the MFA approach in agriculture and the multidimensional analysis of these crops, due to the strong expansion of this management in Andalusia in recent years, currently exceeding $54,800.68$ ha $[9,29,30]$.

In the PDO Estepa, organic olive groves are novel, forming isolated plots immersed in a mosaic of groves managed in an integrated way $[24,39,40]$. This reality is a limitation that must be taken into account when interpreting the results of this research, because although organic olive groves sampled have exceeded the conversion period (i.e., 3 years) as they come from plots under other management models and have organic certification, the absence of a physical separation between this management and integrated farms in the study area may result in the alteration of the biological and soil parameters analysed, due to the risk of diffuse pollution that may exist between contiguous plots [81,89].

According to the simulations carried out over the long term (i.e., 150 years), the sustainable of the organic olive grove in the PDO Estepa was verified from an economic and productive point of view, in agreement with the criteria of Pleguezuelo et al. [29]. In this sense, throughout the simulations, the farms showed an economically profitable character (i.e., benefits in excess of $900 €$ ha $^{-1}$ and $750 €$ ha $^{-1}$ for plots with null and moderate erosion respectively without including the CAP in the analysis, increasing these profits to more than $1200 € \mathrm{ha}^{-1}$ and $1050 € \mathrm{ha}^{-1}$ when the CAP is taken into account), and the production was not lower than $1500 \mathrm{~kg}^{-1}$ olive ha ${ }^{-1}$ or $300 \mathrm{~L}_{\text {olive oil ha }}{ }^{-1}$ (i.e., production threshold below which abandonment is recommended). Analysing the cumulative data, although production was higher in plots with moderate erosion due to higher plant density, cumulative economic benefits were higher under null erosion, again demonstrating the sustainable character of organic agriculture in the study area. Thus, organic management consolidate an agricultural model that responds to the demands of farmers and society in terms of providing a fair standard of living and producing food that meets standards corresponding to food security $[24,29,30]$. However, in line with the studies of Gómez et al. [1,25] and Vanwalleghem et al. [26], erosion has been identified as a threat to soil degradation, with repercussions on olive production due to the generation of less fertile and more compacted soils. Although due to the slight magnitude of erosion estimated in the organic olive groves of the study area erosion did not pose a serious threat to their sustainability over time from an environmental perspective (causing minor environmental and biological impacts), it did lead to a downward trend in production, corroborating the studies of Galán et al. [10] about the main effects of erosion on agricultural yields. On the other hand, plots without erosion showed a higher economic yield, evidencing lower annual costs per farm due to not having to implement measures aimed at maintaining a stable yield $[10,19,46]$.

In a context in which agricultural and olive grove intensification is being promoted as a response to greater production demand [38], the results showed that organic management constitutes a sustainable alternative over time in the Estepa region, taking into account the local character of the research carried out. Thus, organic farming is a model that balances the environmental, productive and socio-economic dimensions of the crop, minimising the environmental impacts of erosion through the implementation of edaphic plant covers $[24,29,36,56]$. From this local perspective, organic farming in the Estepa region makes a high contribution to satisfying existing demands for agriculture, being an alternative agricultural management that meets the multifunctional objectives set out by the CAP and the sustainable development goals (SDGs), contributing especially to the goals related to zero hunger, due to its stable production over time; responsible production and consumption, guaranteeing sustainable crops; action against climate change, by using only organic fertilisers and avoiding land and atmospheric pollution; and the conservation of terrestrial ecosystems, promoting the agro-biodiversity of olive groves and introduc- 
ing measures to mitigate erosion processes (i.e., plant covers) that minimise the risk of desertification $[33,34,90,91]$.

\section{Conclusions}

Taking into account the social demands on agriculture, it is necessary to adopt management models that encourage its sustainability. In this sense, organic farming is a multifunctional model that is increasingly in demand, due to their environmental benefits, which help to ensure the durability of farming systems.

Despite the local/regional character of the research carried out in the PDO Estepa and the reduced sample size of organic olive grove plots, the consequences of erosion as a multidimensional threat that affects the economic and environmental dimensions of the olive grove could be tested. In this sense, erosion caused a slight edaphic degradation on farms, resulting in more compact soils, with higher enzymatic activity and lower content of fine fractions. Erosion also had a negative impact on the diversity and plant covers, as well as on the economic benefits of farms. Additionally, soil contaminants (i.e., nitrates and phosphates) were detected in organic plots, due to diffuse pollution from nearby integrated farms where the use of chemical fertilisers is common.

On the other hand, the simulations carried out showed the sustainability of this crop, with organic management being a sustainable option for Estepa region, configuring an agricultural model which responds to the farmers' demands in terms of employment, maintaining a fair standard of living, and causing minimal environmental impacts.

Future research should be oriented towards the exhaustive analysis of organic management. Broader studies must be carried out, to recommend this management model and promote European subsidies granted to conserve its ES, linking the importance of organic agriculture to the achievement of the SDGs. On the other hand, specific studies should also be carried out, to analyse the local applicability of this management in order to make recommendations to decision-makers on the feasibility and benefits of organic agriculture to each study area.

Author Contributions: Conceptualisation, A.A.R.S. and A.J.R.; methodology, A.A.R.S. and J.M.B.; software, A.A.R.S.; validation, C.P.-L., S.S.-G. and A.J.R.; formal analysis, A.A.R.S. and J.M.B.; investigation, A.A.R.S. and C.P.-L.; resources, A.A.R.S., S.S.-G. and A.J.R.; data curation, A.A.R.S.; writing—original draft preparation, A.A.R.S.; writing—review and editing, A.A.R.S. and A.J.R.; visualisation, A.A.R.S., C.P.-L., J.M.B.; supervision, S.S.-G. and A.J.R.; project administration, A.J.R.; funding acquisition, S.S.-G. and A.J.R. All authors have read and agreed to the published version of the manuscript.

Funding: This research received no external funding.

Institutional Review Board Statement: Not applicable.

Informed Consent Statement: Not applicable.

Data Availability Statement: Not applicable.

Acknowledgments: The main author, Antonio Alberto Rodríguez Sousa (A.A.R.S.), is a postdoctoral researcher contracted by the University Rey Juan Carlos (URJC) and the Autonomous Community of Madrid (CAM), Spain. Acknowledgements are therefore shown to the REMEDINAL TE-CM project, reference S2018/EMT-4338, entitled Conocimiento científico para avanzar hacia la consecución de los Objetivos de Desarrollo Sostenible: una ecología translacional es necesaria (Scientific knowledge to advance towards the achievement of the Sustainable Development Goals: a translational ecology is needed), to which he is linked through the contract identifier number: E-28-2021-0749641. To the University Complutense of Madrid, for providing the main author the opportunity to stay and collaborate with this institution. Finally, to María Aurora Rodríguez Sousa, for her constant support and encouragement throughout the implementation and execution of this research.

Conflicts of Interest: The authors declare no conflict of interest. 


\section{References}

1. Gómez, J.A.; Llewellyn, C.; Basch, G.; Sutton, P.B.; Dyson, J.S.; Jones, C.A. The effects of cover crops and conventional tillage on soil and runoff loss in vineyards and olive groves in several Mediterranean countries. Soil Use Manag. 2011, 27, 502-514. [CrossRef]

2. Amate, J.I.; De Molina, M.G.; Vanwalleghem, T.; Fernández, D.S.; Gómez, J.A. Erosion in the Mediterranean: The Case of Olive Groves in the South of Spain (1752-2000). Environ. Hist. 2013, 18, 360-382. [CrossRef]

3. EUROSTAT. Farm Structure Statistics; Eurostat (European Statistics): Brussels, Belgium, 2018. Available online: https:/ / ec.europa. eu/eurostat/statistics-explained/index.php?title=Farm_structure_statistics/es (accessed on 3 May 2021).

4. CORINE Land Cover. Copernicus Land Monitoring Service; CORINE Land Cover: Copenhagen, Denmark, 2021. Available online: https:/ / land.copernicus.eu/pan-european/corine-land-cover (accessed on 3 May 2021).

5. INE. Agriculture and Environment; INE (Instituto Nacional de Estadística/Statistical Spanish Office): Madrid, Spain, 2014. Available online: https:/ / www.ine.es/dyngs/INEbase/es/categoria.htm?c=Estadistica_P\&cid=1254735727106 (accessed on 27 April 2021).

6. COI. Cifras Aceite de Oliva; COI (Consejo Oleícola Internacional/International Olive Council): Madrid, Spain, 2015. Available online: http:/ / www.internationaloliveoil.org (accessed on 26 April 2021). (In Spanish)

7. COI. OLIVE OIL-PROVISIONAL DATA 2018/19 CROP YEAR; COI (Consejo Oleícola Internacional/International Olive Council): Madrid, Spain, 2018. Available online: http:/ / www.internationaloliveoil.org/olive-oil-provisional-data-2018-19-crop-year/ (accessed on 29 April 2021). (In Spanish)

8. Rodríguez-Entrena, M.; Arriaza, M. Adoption of conservation agriculture in olive groves: Evidences from southern Spain. Land Use Policy 2013, 34, 294-300. [CrossRef]

9. BOJA. Plan Director del Olivar Andaluz Decreto 103/2015; BOJA (Boletín Oficial de la Junta de Andalucía/Official Regional Government of Andalusia Bulletin): Sevilla, Spain, 2015. Available online: http:/ / www.webcitation.org/77MO1YwQe (accessed on 20 April 2021). (In Spanish)

10. Galán, C.; García-Mozo, H.; Vázquez, L.; Ruiz, L.; De La Guardia, C.D.; Domínguez-Vilches, E. Modeling Olive Crop Yield in Andalusia, Spain. Agron. J. 2008, 100, 98-104. [CrossRef]

11. de la Torre, M.G.M.-V.; Fuentes, J.M.A.; Amador-Hidalgo, L. Olive oil tourism: Promoting rural development in Andalusia (Spain). Tour. Manag. Perspect. 2017, 21, 100-108. [CrossRef]

12. Montanaro, G.; Xiloyannis, C.; Nuzzo, V.; Dichio, B. Orchard management, soil organic carbon and ecosystem services in Mediterranean fruit tree crops. Sci. Hortic. 2017, 217, 92-101. [CrossRef]

13. Torres-Miralles, M.; Grammatikopoulou, I.; Rescia, A. Employing contingent and inferred valuation methods to evaluate the conservation of olive groves and associated ecosystem services in Andalusia (Spain). Ecosyst. Serv. 2017, 26, 258-269. [CrossRef]

14. Maldonado, A.D.; Ramos-López, D.; Aguilera, P.A. The Role of Cultural Landscapes in the Delivery of Provisioning Ecosystem Services in Protected Areas. Sustainability 2019, 11, 2471. [CrossRef]

15. Rey, P.J.; Manzaneda, A.J.; Valera, F.; Alcantara, J.; Tarifa, R.; Isla, J.; Pardo, J.L.M.; Calvo, G.; Salido, T.; Gutiérrez, J.E.; et al. Landscape-moderated biodiversity effects of ground herb cover in olive groves: Implications for regional biodiversity conservation. Agric. Ecosyst. Environ. 2019, 277, 61-73. [CrossRef]

16. AEMO. Aproximación a los Costes del Cultivo del Olivo. Cuaderno de Conclusiones del Seminario AEMO; AEMO (Asociación Española de Municipios del Olivo/Spanish Association of Municipalities of Olive Groves): Córdoba, Spain, 2012. Available online: http:/ / www.webcitation.org/77MCvuNPx (accessed on 28 April 2021). (In Spanish)

17. Romero-Gámez, M.; Castro-Rodriguez, J.; Suarez-Rey, E. Optimization of olive growing practices in Spain from a life cycle assessment perspective. J. Clean. Prod. 2017, 149, 25-37. [CrossRef]

18. Orlandi, F.; Sgromo, C.; Bonofiglio, T.; Ruga, L.; Romano, B.; Fornaciari, M. A comparison among olive flowering trends in different Mediterranean areas (south-central Italy) in relation to meteorological variations. Theor. Appl. Clim. 2008, 97, 339-347. [CrossRef]

19. Palese, A.M.; Pergola, M.; Favia, M.; Xiloyannis, C.; Celano, G. A sustainable model for the management of olive orchards located in semi-arid marginal areas: Some remarks and indications for policy makers. Environ. Sci. Policy 2013, 27, 81-90. [CrossRef]

20. Koulouri, M.; Giourga, C. Land abandonment and slope gradient as key factors of soil erosion in Mediterranean terraced lands. Catena 2007, 69, 274-281. [CrossRef]

21. De Graaff, J.; Duarte, F.; Fleskens, L.; De Figueiredo, T.D.A.F.R. The future of olive groves on sloping land and ex-ante assessment of cross compliance for erosion control. Land Use Policy 2010, 27, 33-41. [CrossRef]

22. Sal, A.G.; García, A.G. A comprehensive assessment of multifunctional agricultural land-use systems in Spain using a multidimensional evaluative model. Agric. Ecosyst. Environ. 2007, 120, 82-91. [CrossRef]

23. Parra-López, C.; Calatrava-Requena, J.; De-Haro-Giménez, T. A systemic comparative assessment of the multifunctional performance of alternative olive systems in Spain within an AHP-extended framework. Ecol. Econ. 2008, 64, 820-834. [CrossRef]

24. Rodríguez Sousa, A.A.; Parra-López, C.; Sayadi-Gmada, S.; Barandica, J.; Rescia, A. A multifunctional assessment of integrated and ecological farming in olive agroecosystems in southwestern Spain using the Analytic Hierarchy Process. Ecol. Econ. 2020, 173, 106658. [CrossRef]

25. Gomez, J.A.; Sobrinho, T.A.; Giraldez, J.; Fereres, E. Soil management effects on runoff, erosion and soil properties in an olive grove of Southern Spain. Soil Tillage Res. 2009, 102, 5-13. [CrossRef] 
26. Vanwalleghem, T.; Amate, J.I.; de Molina, M.G.; Fernández, D.S.; Gomez, J.A. Quantifying the effect of historical soil management on soil erosion rates in Mediterranean olive orchards. Agric. Ecosyst. Environ. 2011, 142, 341-351. [CrossRef]

27. Kairis, O.; Karavitis, C.; Kounalaki, A.; Salvati, L.; Kosmas, C. The effect of land management practices on soil erosion and land desertification in an olive grove. Soil Use Manag. 2013, 29, 597-606. [CrossRef]

28. Fernández, J.E.; Moreno, F.; Cabrera, F.; Arrúe, J.L.; Martin-Aranda, J. Drip irrigation, soil characteristics and the root distribution and root activity of olive trees. Plant Soil 1991, 133, 239-251. [CrossRef]

29. Pleguezuelo, C.R.R.; Zuazo, V.H.D.; Martínez, J.R.F.; Peinado, F.J.M.; Martín, F.M.; Tejero, I.F.G. Organic olive farming in Andalusia, Spain. A review. Agron. Sustain. Dev. 2018, 38, 1-16. [CrossRef]

30. EC. Facts and Figures on Organic Agriculture in the European Union. Agriculture and Rural Development; EC (European Comission): Brussels, Belgium, 2013. Available online: https://ec.europa.eu/agriculture/sites/agriculture/files/markets-and-prices/morereports/pdf/organic-2013_en.pdf (accessed on 1 May 2021).

31. EC. The Attitudes of European Citizens towards Environment. Special Eurobarometer 217/Wave 62.1-TNS Opinion E Social; EC (Eu-ropean Commission): Brussels, Belgium, 2005. Available online: http://ec.europa.eu/publicopinion/indexen.htm (accessed on 17 April 2021).

32. EC. Europeans, Agriculture and the CAP. TNS Opinion \& Social. Special Eurobarometer 440; EC (European Commission): Brussels, Belgium, 2016. Available online: http:/ / data.europa.eu/euodp/en/data/dataset/S2087_84_2_440_ENG (accessed on 12 May 2021).

33. Buitenhuis, Y.; Candel, J.; Feindt, P.H.; Termeer, K.; Mathijs, E.; Bardají, I.; Black, J.; Martikainen, A.; Moeyersons, M.; Sorrentino, A. Improving the Resilience-enabling Capacity of the Common Agricultural Policy: Policy Recommendations for More Resilient EU Farming Systems. EuroChoices 2020, 19, 63-71. [CrossRef]

34. Guth, M.; Smędzik-Ambroży, K.; Czyżewski, B.; Stępień, S. The Economic Sustainability of Farms under Common Agricultural Policy in the European Union Countries. Agriculture 2020, 10, 34. [CrossRef]

35. Rodríguez Sousa, A.A.; Parra-López, C.; Sayadi-Gmada, S.; Barandica, J.M.; Rescia, A.J. Evaluation of the Objectives and Concerns of Farmers to Apply Different Agricultural Managements in Olive Groves: The Case of Estepa Region (Southern, Spain). Land 2020, 9, 366. [CrossRef]

36. Rodríguez Sousa, A.A.; Barandica, J.M.; Sanz-Cañada, J.; Rescia, A.J. Application of a dynamic model using agronomic and economic data to evaluate the sustainability of the olive grove landscape of Estepa (Andalusia, Spain). Landsc. Ecol. 2019, 34, 1547-1563. [CrossRef]

37. INE. Economy; INE (Instituto Nacional de Estadística/Statistical Spanish Office): Madrid, Spain, 2018. Available online: https:/ / www.ine.es /dyngs /INEbase/es /operacion.htm?c=Estadistica_C\&cid=1254736167628\&menu=resultados\&idp=1254735576581 (accessed on 22 April 2021).

38. Sánchez-Escobar, F.; Coq-Huelva, D.; Sanz-Cañada, J. Measurement of sustainable intensification by the integrated analysis of energy and economic flows: Case study of the olive-oil agricultural system of Estepa, Spain. J. Clean. Prod. 2018, 201, 463-470. [CrossRef]

39. Cañada, J.S.; Vázquez, A.M. Quality certification, institutions and innovation in local agro-food systems: Protected designations of origin of olive oil in Spain. J. Rural. Stud. 2005, 21, 475-486. [CrossRef]

40. BOJA. Pliego de Condiciones de la Denominación de Origen Protegida Estepa; BOJA (Boletín Oficial de la Junta de Andalucía/Official Regional Government of Andalusia Bulletin): Sevilla, Spain, 2015. Available online: https://www.webcitation.org/77MOBd5Gh (accessed on 5 April 2021). (In Spanish)

41. BOJA. Ministry of Employment, Business and Commerce; BOJA (Boletín Oficial de la Junta de Andalucía/Official Regional Government of Andalusia Bulletin): Andalusia, Spain, 2015. Available online: https://www.juntadeandalucia.es/organismos/ empleoempresaycomercio/areas/industria/seguridad/paginas/denominaciones-calidad-aceite-oliva.html (accessed on 8 April 2021). (In Spanish)

42. Anaya-Romero, M.; Abd-Elmabod, S.K.; Muñoz-Rojas, M.; Castellano, G.; Ceacero, C.J.; Álvarez, S.; Mendez, M.; De La Rosa, D. Evaluating Soil Threats Under Climate Change Scenarios in the Andalusia Region, Southern Spain. Land Degrad. Dev. 2015, 26, 441-449. [CrossRef]

43. Rodríguez Sousa, A.A.; Barandica, J.M.; Rescia, A.J. Estimation of Soil Loss Tolerance in Olive Groves as an Indicator of Sustainability: The Case of the Estepa Region (Andalusia, Spain). Agronomy 2019, 9, 785. [CrossRef]

44. Arampatzis, G.; Hatzigiannakis, E.; Pisinaras, V.; Kourgialas, N.; Psarras, G.; Kinigopoulou, V.; Panagopoulos, A.; Koubouris, G. Soil water content and olive tree yield responses to soil management, irrigation, and precipitation in a hilly Mediterranean area. $J$. Water Clim. Chang. 2018, 9, 672-678. [CrossRef]

45. Capra, A.; Scicolone, B. Irrigation Scheduling Optimisation in Olive Groves. J. Exp. Agric. Int. 2018, 28, 1-19. [CrossRef]

46. Rodríguez Sousa, A.A.; Barandica, J.M.; Rescia, A. Ecological and Economic Sustainability in Olive Groves with Different Irrigation Management and Levels of Erosion: A Case Study. Sustainability 2019, 11, 4681. [CrossRef]

47. Martínez-Núñez, C.; Rey, P.J.; Salido, T.; Manzaneda, A.J.; Camacho, F.M.; Isla, J. Ant community potential for pest control in olive groves: Management and landscape effects. Agric. Ecosyst. Environ. 2021, 305, 107185. [CrossRef]

48. SIOSE. Plan Nacional Para la Observación del Territorio: Sistema de Información Sobre Ocupación del Suelo en España; SIOSE (Sistema de Información sobre Ocupación del Suelo de España/Information System on Land Use in Spain): Madrid, Spain, 2011. Available online: www.siose.es (accessed on 1 April 2021). (In Spanish) 
49. MAPAMA. Mapa de estados erosivos (1987-2001); MAPAMA (Ministerio de Agricultura, Alimentación y Medio Ambien-te/Ministry of Agriculture, Food and Environment): Madrid, Spain, 2017. Available online: http:/ /www.mapama.gob.es/es/biodiversidad/ servicios/banco-datos-naturaleza/informacion-disponible/mapas_estados_erosivos.aspx (accessed on 17 April 2021). (In Spanish)

50. Moreira-Madueño, J.M. Capacidad de uso y Erosión de Suelos. Una Aproximación a la Evaluación de Tierras en Andalucía; Junta de Andalucía (Andalusia Government): Seville, Spain, 1991. Available online: http:/ /www.juntadeandalucia.es/medioambiente/ web/Red_informacion_ambiental/productos/Publicaciones/articulos/articulos_pdf/Paralelo.PDF (accessed on 18 January 2019). (In Spanish)

51. Wischmeier, W.H.; Smith, D.D. A universal soil-loss equation to guide conservation farm planning. Trans. Int. Congr. Soil Sci. 1960, 1, 418-425. Available online: https: / / www.cabdirect.org/cabdirect/abstract/19621901607 (accessed on 29 April 2021).

52. Fistikoglu, O.; Harmancioglu, N.B. Integration of GIS with USLE in Assessment of Soil Erosion. Water Resour. Manag. 2002, 16, 447-467. [CrossRef]

53. Gómez-Calero, J.A. Sostenibilidad de la Producción de Olivar en Andalucía. Instituto de Agricultura Sostenible. Instituto de Agricultura Sostenible, Centro Superior de Investigaciones Científicas; Instituto de Agricultura Sostenible: Córdoba, Spain, 2010. Available online: https:/ /www.ias.csic.es/sostenibilidad_olivar/Sost_2009/Sostenibilidad_de_la_Producci\%F3n_de_Olivar_en_Andaluc\% EDa3.pdf (accessed on 2 April 2021). (In Spanish)

54. Sánchez Escobar, F. Sistemas Complejos: Una Aplicación para el Análisis de los Balances Energéticos y Económicos en el Agrosistema de Olivar de Estepa. Ph.D. Thesis, University of Sevilla, Sevilla, Spain, 2015.

55. Gisbert Blanquer, J.M.; Ibañez Asensio, S.; Moreno Ramón, H. El Factor K de la Ecuación Universal de Pérdidas de Suelo (USLE); Universitat Politècnica de València: Valencia, Spain, 2012. Available online: http:/ /hdl.handle.net/10251/16850 (accessed on 21 April 2021). (In Spanish)

56. Gómez, J.; Battany, M.; Renschler, C.S.; Fereres, E. Evaluating the impact of soil management on soil loss in olive orchards. Soil Use Manag. 2006, 19, 127-134. [CrossRef]

57. Narayanan, N.; Ramamurthy, K. Structure and properties of aerated concrete: A review. Cem. Concr. Compos. 2000, 22, 321-329. [CrossRef]

58. Laudicina, V.A.; Novara, A.; Barbera, V.; Egli, M.; Badalucco, L. Long-Term Tillage and Cropping System Effects on Chemical and Biochemical Characteristics of Soil Organic Matter in a Mediterranean Semiarid Environment. Land Degrad. Dev. 2014, $26,45-53$. [CrossRef]

59. Carlos, F.S.; Schaffer, N.; Marcolin, E.; Fernandes, R.S.; Mariot, R.; Mazzurana, M.; Roesch, L.F.W.; Levandoski, B.; Camargo, F.A.D.O. A long-term no-tillage system can increase enzymatic activity and maintain bacterial richness in paddy fields. Land Degrad. Dev. 2021, 32, 2257-2268. [CrossRef]

60. Pavlidis, G.; Tsihrintzis, V.A. Environmental Benefits and Control of Pollution to Surface Water and Groundwater by Agroforestry Systems: A Review. Water Resour. Manag. 2018, 32, 1-29. [CrossRef]

61. Sasakova, N.; Gregova, G.; Takacova, D.; Mojzisova, J.; Papajová, I.; Venglovsky, J.; Szaboova, T.; Kovacova, S. Pollution of Surface and Ground Water by Sources Related to Agricultural Activities. Front. Sustain. Food Syst. 2018, 2, 42. [CrossRef]

62. De Torres, M.A.R.-R.; Ordóñez-Fernández, R.; Moreno-García, M.; Márquez-García, J.; Carbonell-Bojollo, R.M. Carbon sequestration by grass, crucifer and legume groundcovers in olive orchards. J. Water Clim. Chang. 2018, 9, 748-763. [CrossRef]

63. Nagendra, H. Opposite trends in response for the Shannon and Simpson indices of landscape diversity. Appl. Geogr. 2002, 22, 175-186. [CrossRef]

64. Keylock, C.J. Simpson diversity and the Shannon-Wiener index as special cases of a generalized entropy. Oikos 2005, 109, 203-207. [CrossRef]

65. STELLA. Dynamic System Software; STELLA 9.1.4; Isee Systems Inc.: Lebanon, PA, USA, 2010. Available online: https:/ /www. iseesystems.com/store/products/stella-online.aspx (accessed on 15 April 2021).

66. Gómez-Calero, J.A. Olivar Sostenible: Prácticas para una Producción Sostenible de olivar en Andalucía; Instituto de Agricultura Sostenible, Centro Superior de Investigaciones Científicas: Córdoba, Spain, 2010. Available online: https://www.ias.csic.es/ sostenibilidad_olivar/BPA_VF_Jan2010.pdf (accessed on 12 April 2021). (In Spanish)

67. Yang, Y.; Mathew, T. The simultaneous assessment of normality and homoscedasticity in linear fixed effects models. J. Stat. Theory Pract. 2017, 12, 66-81. [CrossRef]

68. Ruxton, G.D. The unequal variance t-test is an underused alternative to Student's t-test and the Mann-Whitney U test. Behav. Ecol. 2006, 17, 688-690. [CrossRef]

69. Fay, M.P.; Proschan, M.A. Wilcoxon-Mann-Whitney or t-test? On assumptions for hypothesis tests and multiple interpretations of decision rules. Stat. Surv. 2010, 4, 1-39. [CrossRef]

70. RStudio, version 0.98.1102; Open Source and Enterprise-Ready Professional Software for R; RStudio Inc.: Boston, MA, USA, 2009-2014. Available online: https:/ / www.rstudio.com/products/RStudio/ (accessed on 1 April 2021).

71. SPSS. IBM Statistical Package for the Social Sciences for Windows; SPSS Version 21.0; IBM Corp: Armonk, NY, USA, 2012. Available online: https://www.ibm.com/es-es/analytics/spss-statistics-software (accessed on 7 April 2021).

72. Lawson, J. Design and Analysis of Experiments with R, 1st ed.; Chapman and Hall/CRC: New York, NY, USA, 2014 ; pp. 65-150. 
73. Rodriguez-Entrena, M.; Espinosa, M.; Barreiro-Hurle, J. The role of ancillary benefits on the value of agricultural soils carbon sequestration programmes: Evidence from a latent class approach to Andalusian olive groves. Ecol. Econ. 2014, $99,63-73$. [CrossRef]

74. Guzmán-Álvarez, J.R.; Navarro-Cerrillo, R.M. Modelling potential abandonment and natural restoration of marginal olive groves in Andalusia (south of Spain). J. Land Use Sci. 2008, 3, 113-129. [CrossRef]

75. Paredes, D.; Karp, D.S.; Chaplin-Kramer, R.; Benítez, E.; Campos, M. Natural habitat increases natural pest control in olive groves: Economic implications. J. Pest Sci. 2019, 92, 1111-1121. [CrossRef]

76. Michalopoulos, G.; Kasapi, K.A.; Koubouris, G.; Psarras, G.; Arampatzis, G.; Hatzigiannakis, E.; Kavvadias, V.; Xiloyannis, C.; Montanaro, G.; Malliaraki, S.; et al. Adaptation of Mediterranean Olive Groves to Climate Change through Sustainable Cultivation Practices. Climate 2020, 8, 54. [CrossRef]

77. Hermosin, M.; Calderon, M.; Real, M.; Cornejo, J. Impact of herbicides used in olive groves on waters of the Guadalquivir river basin (southern Spain). Agric. Ecosyst. Environ. 2013, 164, 229-243. [CrossRef]

78. Caravaca, F.; Lax, A.; Albaladejo, J. Soil aggregate stability and organic matter in clay and fine silt fractions in urban refuseamended semiarid soils. Soil Sci. Soc. Am. J. 2001, 65, 1235-1238. [CrossRef]

79. Li, Y.; Niu, W.; Wang, J.; Liu, L.; Zhang, M.; Xu, J. Effects of Artificial Soil Aeration Volume and Frequency on Soil Enzyme Activity and Microbial Abundance when Cultivating Greenhouse Tomato. Soil Sci. Soc. Am. J. 2016, 80, 1208-1221. [CrossRef]

80. Ben-Noah, I.; Friedman, S.P. Review and Evaluation of Root Respiration and of Natural and Agricultural Processes of Soil Aeration. Vadose Zone J. 2018, 17, 170119. [CrossRef]

81. Lopez-Pintor, A.; Sanz-Cañada, J.; Salas, E.; Rescia, A. Assessment of Agri-Environmental Externalities in Spanish Socio-Ecological Landscapes of Olive Groves. Sustainability 2018, 10, 2640. [CrossRef]

82. Duan, X.-W.; Xie, Y.; Feng, Y.-J.; Yin, S.-Q. Study on the Method of Soil Productivity Assessment in Black Soil Region of Northeast China. Agric. Sci. China 2009, 8, 472-481. [CrossRef]

83. Duan, X.; Shi, X.; Li, Y.; Rong, L.; Fen, D. A new method to calculate soil loss tolerance for sustainable soil productivity in farmland. Agron. Sustain. Dev. 2016, 37, 2. [CrossRef]

84. Tavoni, M.; Kriegler, E.; Riahi, K.; van Vuuren, D.; Aboumahboub, T.; Bowen, A.; Calvin, K.; Campiglio, E.; Kober, T.; Jewell J.; et al. Post-2020 climate agreements in the major economies assessed in the light of global models. Nat. Clim. Chang. 2015, 5, 119-126. [CrossRef]

85. Quintero-Angel, M.; González-Acevedo, A. Tendencies and challenges for the assessment of agricultural sustainability. Agric. Ecosyst. Environ. 2018, 254, 273-281. [CrossRef]

86. Lampridi, M.G.; Sørensen, C.G.; Bochtis, D. Agricultural Sustainability: A Review of Concepts and Methods. Sustainability 2019, 11, 5120. [CrossRef]

87. Tamburini, E.; Pedrini, P.; Marchetti, M.G.; Fano, E.A.; Castaldelli, G. Life Cycle Based Evaluation of Environmental and Economic Impacts of Agricultural Productions in the Mediterranean Area. Sustainability 2015, 7, 2915-2935. [CrossRef]

88. Daniel, E. Towards Sustainable Organic Farming Systems. Sustainability 2020, 12, 9832. [CrossRef]

89. BOE. Ley 5/2011, de 6 de Octubre, del Olivar de Andalucia; BOE (Boletín Oficial del Estado/State Official Bulletin): Andalusia, Spain, 2011. Available online: https:/ / www.boe.es/buscar/act.php?id=BOE-A-2011-17494 (accessed on 27 April 2021). (In Spanish)

90. Fukuda-Parr, S. From the Millennium Development Goals to the Sustainable Development Goals: Shifts in purpose, concept, and politics of global goal setting for development. Gend. Dev. 2016, 24, 43-52. [CrossRef]

91. Biermann, F.; Kanie, N.; Kim, R.E. Global governance by goal-setting: The novel approach of the UN Sustainable Development Goals. Curr. Opin. Environ. Sustain. 2017, 26-27, 26-31. [CrossRef] 